\title{
The effect of chronic lead acetate trihydrate intoxication in Wistar rats on experimental Ascaris suum infestation and immunity
}

\author{
J. PISTL, I. KRUPICER, N. KOVALKOVIČOVÁ, J. LEGÁTH, M. FALIS, J. POLLÁKOVÁ, K. BEŇOVÁ, \\ R. SABO
}

University of Veterinary Medicine, Komenského 73, 04181 Košice, Slovakia, E-mail: kovalkovicova@uvm.sk

\begin{abstract}
Summary
SPF male Wistar rats were exposed for four months to lead acetate trihydrate present in drinking water $(100 \mathrm{mg} / \mathrm{l})$ and subsequently infested with $1000 \pm 100$ infective $A$. suum eggs. Metabolic activity of phagocytes and proliferative activity of T-lymphocytes were investigated on Day 4 and 8 after $A$. suum eggs infestation (Day 130 and 134 of lead acetate trihydrate exposition). The results demonstrated that treatment with lead acetate trihydrate led to increased susceptibility to infestation, manifested by increased average number of $A$. suum larvae in the lungs of exposed rats compared to unexposed ones. Moreover, migration of $A$. suum larvae on Day 8 was associated with significant increase in index of metabolic activity of phagocytes in unexposed rats in comparison with controls. In contrast, in rats exposed to the lead and infested by $A$. suum eggs a non-significant increase in the studied immunological parameters was recorded. Significant differences in immunological parameters were observed between unexposed, infested and infested and exposed groups of rats. In the unexposed group of animals Ascaris suum infestation caused a significant increase in the index of metabolic activity of phagocytes and stimulation index of lymphocytes in comparison with lead exposed rats.
\end{abstract}

Key words: lead acetate trihydrate; Ascaris suum; metabolic activity of phagocytes; stimulation index of lymphocytes; rat

\section{Introduction}

Rapid industrialization in the past decades and increasing awareness of environmental pollution has led to a corresponding revival of interest in metals as potential immunotoxicants. In recent years, there has been an increased concern about the accumulation of lead in the environment. Lead, today, remains an economically important commodity. It is highly reactive and forms numerous compounds with very different physical-chemical properties, e.g. solubility that affects their bioavailability. One of the major soluble lead compounds is lead acetate trihydrate. It is used as a mordant in cotton dyes, in antifouling paints and insecticides, as a lead coating for metals, as a drier in paints, varnishes, pigment inks, as a colorant in hair dyes and as a processing agent in the cosmetics, perfume and toiletry industries (IARC, 2004). The primary routes of potential exposure to it are ingestion, inhalation or dermal contact and it is absorbed about 1.5 times faster than any other lead compound.

Lead acetate has an important immunotoxicity for the phagocytic activity as well as humoral and cell-mediated immunity; however, the manner in which it affects the immune cells is not completely understood (Institoris et al., 1999; Bunn et al., 2001; Dietert et al., 2004; Bishayi \& Sengupta, 2006). Its immunosuppressive effect may cause an increased susceptibility of exposed individuals to infection, infestation or the occurrence of tumors.

There have been several authors that have studied the effects of metals in relation to parasites and their hosts. An immunosuppressive effect of heavy metal emissions from mercury producing factories was registered in lambs experimentally infected by Fasciola hepatica. Necropsy revealed an increased occurrence of these trematodes in exposed animals (Krupicer et al., 1996). Moreover, an increased prevalence of gastrointestinal nematodes was discovered in heavy metal exposed lambs (Borošková et al., 1995; Pistl et al., 1995) or in sheep grazing on pastures polluted with mercury fall (Krupicer \& Pet'ko, 1992; Krupicer, 1995). The concentration of metal in sheep organism was dependent on age, duration of exposure, distance from emission source, meteorological conditions and terrain configuration (Krupicer \& Juriš, 1996). Borošková et al. (1993) observed 8 times higher intensity of infection by Ascaris suum in guinea pigs exposed to immissions containing metals with dominance of mercury. This study 
was aimed at determining the effect on experimental $A s$ caris suum infestation in male Wistar rats SPF of the chronic exposure to lead acetate trihydrate with emphasis on the relationship with biological activity of immune system cells.

\section{Material and Methods}

\section{Animals and experimental design}

48 clinically healthy male Wistar rats SPF, 6-month-old, were obtained from accredited breeding station Central Zodiac of the Medical Faculty, University of P. J. Šafarik in Košice, Slovak Republic. There were 12 males weighing $464.0 \pm 44.92 \mathrm{~g}$ in the control group (C 1 - C 12); 12 males weighing $444.2 \pm 33.08 \mathrm{~g}$ in group exposed to $100 \mathrm{mg}$ lead acetate trihydrate per liter of drinking water (E $1-\mathrm{E}$ 12); 12 males with mean b.wt. $452.33 \pm 23.54 \mathrm{~g}$ infested by $A$. suum ova (I $1-$ I 12) and 12 males with mean b.wt. $426.33 \pm 21.69 \mathrm{~g}$ exposed to $100 \mathrm{mg} / \mathrm{l}$ of lead acetate trihydrate and then infested with $A$. suum ova (EI 1 - EI 12). Animals were acclimatized for 1 week and housed in plastic cages (VELAZ Praha, Czech Republic). Food and water were offered ad libitum throughout the experiment. Animal quarters were maintained at $22{ }^{\circ} \mathrm{C}\left( \pm 2{ }^{\circ} \mathrm{C}\right)$ with $30-70 \%$ relative humidity and $12 \mathrm{~h}$ light/dark regimen.

Feed consumption, general appearance and any other clinical symptoms (e.g. diarrhea, respiratory distress, spasms, ataxia) were monitored daily. Body weight was recorded weekly.

This experiment was approved by the State Veterinary and Food Authority of the Slovak Republic, Approval RO7879/04-220/3, 21.2.2005.

Table 1. Physical-chemical properties of lead acetate trihydrate (ATSDR, 2005; Cheminfo, 2006)

\begin{tabular}{|c|c|}
\hline Substance name & Lead acetate trihydrate \\
\hline Molecular formula & $\mathrm{Pb}\left(\mathrm{CH}_{3} \mathrm{COO}\right)_{2} \cdot 3 \mathrm{H}_{2} \mathrm{O}$ \\
\hline Produce & Lachema, Brno \\
\hline CAS RN & $6080-56-4$ \\
\hline Colour & Colourless crystalline substance \\
\hline MW & 379.33 \\
\hline $\begin{array}{l}\text { Specific gravity } \\
(\text { water }=1)\end{array}$ & 2.55 \\
\hline Melting point ${ }^{\circ} \mathrm{C}$ & 75 \\
\hline Boiling point ${ }^{\circ} \mathrm{C}$ & 280 \\
\hline Stability & $\begin{array}{l}\text { Upon heating, it loses some of its } \\
\text { water of crystallization. Above } \\
100{ }^{\circ} \mathrm{C} \text {, it begins to lose some } \\
\text { acetic acid and it decomposes } \\
\text { completely at } 200{ }^{\circ} \mathrm{C}\end{array}$ \\
\hline Solubility & $\begin{array}{l}45.61 \mathrm{~g} / 100 \mathrm{ml} \text { water at } 15{ }^{\circ} \mathrm{C} \text {; } \\
\text { slightly soluble in ethanol and } \\
\text { acetone; soluble in glycerol; } \\
\text { sensitive to air; reagent for } \\
\text { neutralization of amino acids and } \\
\text { hydrochlorides }\end{array}$ \\
\hline Purity & 99.5 \\
\hline
\end{tabular}

\section{Dose and exposure}

Twenty four experimental animals (E 1 - E 12 and EI 1 EI 12) were exposed for 125 days to a dose of $100 \mathrm{mg}$ of lead acetate trihydrate per liter of drinking water. Lead acetate trihydrate was freshly prepared in water each day and rats were exposed to it via drinking water. Table 1 shows physical-chemical properties of lead acetate trihydrate (ATSDR, 2005; Cheminfo, 2006).

\section{Infestation by $A$. suum eggs}

On Day 126 twenty four animals, I 1 - I 12 and EI 1 - EI 12 , were per orally infested with $1000 \pm 100$ infective Ascaris suum ova. Eggs used for infestation of the rats were collected from the uteri of adult $A$. suum females.

Uteri were homogenized and rinsed by distilled water containing $0.1 \% \mathrm{NaOH}$ and then eggs were incubated at $27{ }^{\circ} \mathrm{C}$ for 21 days to develop into infective stage.

Rats were sacrificed on Day 4 and 8 after infestation (i.e. on Day 130 and 134 of experiment, respectively) by cervical dislocation (I. and II. collection). The number of migratory larvae was counted in the liver and lungs after their homogenization by Baermann method (Garcia, 2007).

\section{Sampling procedure}

Blood samplings obtained from the cardiac puncture were withdrawn from rats into $1.5 \%$ EDTA on Day 4 and 8 after infestation (i.e. on Day 130 and 134 of experiment, respectively). Leukocytes were isolated from whole blood by red cell lysis in ACK buffer $\left(8.29 \mathrm{~g} / 1 \mathrm{NH}_{4} \mathrm{Cl}, 1.0 \mathrm{~g} / \mathrm{l}\right.$ $\mathrm{KHCO}_{3}$, and $1 \mathrm{mM}$ EDTA in aqua deaminata). Samples incubated on ice were centrifuged for $10 \mathrm{~min}$ at $2000 \mathrm{rpm}$ (MPW-340, Mechanika Precyzyjna, Warsaw, Poland). Leukocyte pellets were further washed three times in sterile $\mathrm{PBS}$ and resuspended to a final concentration of $1 \times 10^{7} / \mathrm{ml}$.

\section{Immunological assays}

\section{Iodo-Nitro-Tetrazolium Reductase Test (INT)}

Quantitative evaluation of tetrazolium reductase metabolic activity of phagocytes was performed according to the method of Lokaj and Oburkova (1975). The cell suspensions $\left(1 \times 10^{7} / \mathrm{ml}\right)$ were prepared and maintained in complete RPMI 1640 medium containing 25 mM HEPES, $0.3 \mathrm{mg} / \mathrm{ml}$ L-glutamine (Gibco, Invitrogen $\mathrm{GmbH}$, Karlsruhe, Germany), supplemented with $100 \mu \mathrm{g} / \mathrm{ml}$ streptomycin, $100 \mathrm{IU} / \mathrm{ml}$ penicillin (Gibco, Invitrogen $\mathrm{GmbH}$, Karlsruhe, Germany) and $10 \%$ foetal calf serum (Gibco, Invitrogen GmbH, Karlsruhe, Germany). Leukocyte suspensions from each animal were then divided into 2 parts. One portion of leukocytes was incubated at $37{ }^{\circ} \mathrm{C}$ for $45 \mathrm{~min}$ with starch $(1 \%$ suspension of Amylum oryzae in phosphate-buffered saline) alone. The second one was incubated under the same conditions, but without starch. All cell suspensions tested in triplicate $\left(1 \times 10^{6}\right.$ cells/tube) were treated with $0.1 \%$ INT (3/4-iodophenyl-2-/4-nitrophenyl/-5-phenyl/-tetrazolium chloride, Lachema, Brno, Czech Republic). Immediately after 45 min incubation, the cells were lyzed with methanol and the 
content of released formasan in the supernatant (red coloured product after INT reduction) was determined spectrophotometrically at $485 \mathrm{~nm}$ (Spectronic Genesys ${ }^{\mathrm{TM}}$ 5, Spectronic Instruments Inc., USA). The results were described in the form of an index of metabolic activity (IMA) based on the ratio of mean optical density $\left(\mathrm{OD}_{485}\right)$ of leukocyte suspensions with starch (actually phagocytic cells - an increased metabolism) to the leukocyte suspensions without the starch (phagocytes without stress a basic metabolism).

$$
\mathrm{IMA}=\frac{\mathrm{OD}_{485} \text { leukocyte suspensions with starch }}{\mathrm{OD}_{485} \text { leukocyte suspensions without starch }}
$$

\section{Lympho-proliferation assay (LPA)}

A colorimetric immunoassay was used for the quantification of lymphocyte proliferation, based on the measurement of 5-bromo-2'-deoxyuridine (BrdU) incorporation during DNA synthesis (Cell Proliferation ELISA Kit, BrdU-colorimetric, Roche Diagnostics GmbH, Penzberg, Germany). The $100 \mu 1$ of $10^{5}$ cells/well suspensions of rat lymphocytes were cultured in complete RPMI 1640 for 72 hrs with $10 \mu \mathrm{g} / \mathrm{ml}$ or without mitogen (phytohemagglutinin, PHA, Sigma, Germany). Each cell culture was incubated for 4 days at $37{ }^{\circ} \mathrm{C}$ in $5 \% \mathrm{CO}_{2}$ atmosphere in tripli-
The immunotoxic effect was characterized as a decreased ability of lymphocytes to respond to the mitogenic stimuli of PHA (PHA - polyclonal activator of T-lymphocytes). Statistical analysis

The results were evaluated statistically by the ANOVA test. Differences between treated groups and control were analysed using Student's $t$-test.

\section{Results}

During the entire study no overt signs of toxicity, body weight or food consumption changes were observed in any experimental group.

In the group of infested animals (I 1 - I 6) and group of animals exposed to lead acetate trihydrate and infested by A. suum eggs (EI 1 - EI 6), sacrificed on Day 4 after infestation, necropsy revealed white-spot lesions in the livers of these rats. In lead acetate trihydrate exposed uninfested rats no gross pathological changes in the livers were observed.

In the group of rats sacrificed on Day 8 after infestation (i.e. animals I 7 - I 12 and EI 7 - EI 12) white-spot lesions in the livers and nodules in the lungs were observed. This is associated with fact that in non-specific host larvae of Ascaris suum firstly migrate into the liver on Day $3-4$, then into the lungs on Day $7-8$ after infestation.

Table 2. Number of $A$. suum larvae in the liver and lungs of rats

\begin{tabular}{lcccccc}
\hline \multicolumn{1}{c}{ Group } & Animals & \multicolumn{2}{c}{ I. collection } & Animals & \multicolumn{2}{c}{ II. collection } \\
& & Liver & Lungs & & & Lungs \\
\hline I & & & & & & \\
Mean \pm SD & $1-6$ & $69.7 \pm 29.5$ & - & $7-12$ & $8.7 \pm 5.0$ & $83.2 \pm 15.0$ \\
\hline EI & $1-6$ & $84.3 \pm 20.9^{\mathrm{ns}}$ & - & $7-12$ & $17.2 \pm 11.3^{\mathrm{ns}}$ & $118.0 \pm 36.6^{\mathrm{ns}}$ \\
Mean \pm SD & $1-6$
\end{tabular}

I - infested by A. suum eggs; EI - exposed to lead acetate trihydrate and infested by $A$. suum eggs; ${ }^{\text {ns }}$ - statistically non-significant difference; $\mathrm{SD}$ - standard deviation

cates in a 96-well microtiter plates (Nunc, Roskilde, Denmark). Eighteen hours before the end of cultivation, BrdU in concentration of $100 \mu \mathrm{M}$ was added. Tissue culture plates were then centrifuged (Nüve, Ankara, Turkey) at $2000 \mathrm{rpm}$ for $10 \mathrm{~min}$ and the labeling medium was removed by flicking off. After removing the medium, denaturation of DNA and fixation of the cells on the bottom of wells was performed according to general assay procedure of Instruction manual. Subsequently anti-BrdU-peroxidase labelled conjugate $(100 \mu \mathrm{l} /$ well $)$ was added for $90 \mathrm{~min}$ at room temperature. The immune complexes were detected by the substrate solution ( $100 \mu \mathrm{l} /$ well substrate solution) in $30 \mathrm{~min}$ at room temperature. Reaction was stopped by 25 $\mu \mathrm{l} 1 \mathrm{M} \mathrm{H}_{2} \mathrm{SO}_{4}$ and the absorbance was measured in an ELISA reader at $450 \mathrm{~nm}$ ( $\mu$ Quant Biomolecular Spectrophotometer MQX200 BioTek Instruments Inc., USA).

The cell activation rate was calculated as a stimulating index (SI) of lymphocytes according to formula:

$$
\mathrm{SI}=\frac{\mathrm{OD}_{450} \text { PHA stimulated lymphocytes }}{\mathrm{OD}_{450} \text { not stimulated lymphocytes }}
$$

Numbers of $A$. suum larvae in the liver and lungs of rats are presented in Table 2 . In the group of rats exposed to lead acetate trihydrate and infested by $A$. suum eggs (EI 1 EI 12) slightly higher numbers of $A$. suum larvae in the liver and lungs were observed in comparison with untreated group. On Day 8 after infestation the average number of $A$. suum larvae in the lungs of rats exposed to lead acetate trihydrate and infected by $A$. suum eggs (EI 7 - EI 12) was slightly increased compared to unexposed group (I 7 I $12, \mathrm{p}=0.057)$. On Day $2-8$ after infestation the presence of $A$. suum larvae in feces was not detected.

Migration of $A$. suum larvae was combined with a significant increase in IMA of phagocytes $(\mathrm{P}=0.0015)$ and mild increase in SI of lymphocytes $(\mathrm{P}=0.078)$ in unexposed rats on Day 8 after infestation (I 7 - I 12). In rats that were exposed to lead acetate trihydrate and infested by $A$. suum eggs (EI 7 - EI 12) only mild, non-significant increase in IMA of phagocytes and SI of lymphocytes on Day 8 after infestation was recorded (Table 3, 4).

Mean values of IMA of phagocytes in lead acetate trihydrate exposed uninfested rats (E $1-\mathrm{E} 6$ and $\mathrm{E} 7-\mathrm{E} 12)$ were significantly decreased in both collections (on Day 
Table 3. Index of metabolic activity of rat peripheral blood phagocytes after chronic exposure to lead acetate trihydrate and infestation by A. suum eggs

\begin{tabular}{cclll}
\hline Group & Animals & I. collection & Animals & II. collection \\
\hline $\begin{array}{c}\mathbf{C} \\
\text { Mean } \pm \mathrm{SD}\end{array}$ & $1-6$ & $2.76 \pm 0.33$ & $7-12$ & $2.76 \pm 0.41$ \\
\hline $\begin{array}{c}\mathbf{I} \\
\text { Mean } \pm \mathrm{SD}\end{array}$ & $1-6$ & $2.82 \pm 0.06$ & $7-12$ & $4.26 \pm 0.75^{\mathrm{e}^{* *}}$ \\
\hline $\begin{array}{c}\mathbf{E} \\
\text { Mean } \pm \mathrm{SD}\end{array}$ & $1-6$ & $2.13 \pm 0.26^{\mathrm{a}^{* *} \mathrm{c}^{* * *}}$ & $7-12$ & $2.06 \pm 0.14^{\mathrm{f}^{* * *}}$ \\
\hline $\begin{array}{c}\text { EI } \\
\text { Mean } \pm \mathrm{SD}\end{array}$ & $1-6$ & $2.17 \pm 0.25^{\mathrm{b}^{* *} ; \mathrm{d}^{* * *}}$ & $7-12$ & $3.15 \pm 0.52^{\mathrm{a}^{* *} ; \mathrm{h}^{* *}}$ \\
\hline
\end{tabular}

C - control; I - infested by A. suum eggs; E - exposed to lead acetate trihydrate; EI - exposed to lead acetate trihydrate and infested by $A$. suum eggs; $* \mathrm{p}<0.05 ; * * \mathrm{p}<0.01 ; * * * \mathrm{p}<0.001$

Significant difference between groups: $\mathrm{a}^{* *}-\mathrm{C}$ and $\mathrm{E} ; \mathrm{b}^{* *}-\mathrm{C}$ and $\mathrm{EI} ; \mathrm{c} * * *-\mathrm{I}$ and $\mathrm{E}$;

$\mathrm{e}^{* *}-\mathrm{C}$ and $\mathrm{I} ; \mathrm{f}^{* * *}-\mathrm{I}$ and $\mathrm{E} ; \mathrm{d}^{* * *}, \mathrm{~g}^{* *}-\mathrm{I}$ and $\mathrm{EI} ; \mathrm{h}{ }^{* *}-\mathrm{E}$ and $\mathrm{EI}$

130 and 134 of exposure) ( $\mathrm{P}=0.0042$ and 0.0027 , respectively) compared to control group of animals (Table 3 ). Similar results were also registered after activation of lymphocytes with PHA, as mean values of SI lymphocytes were significantly decreased in comparison with control $(\mathrm{P}$ $=0.0015$ and 0.0004 , respectively) suggesting decreased mitogenic activation of lymphocytes (Table 4).

In both collections (Day 4 and 8 after infestation) a significant difference in mean values of IMA of phagocytes and in SI of lymphocytes was observed between infested and exposed rats (I 1 - I 6 vs. E 1 - E 6 and I 7 - I 12 vs. E 7 E 12) and between infested and infested and exposed rats (I 1 - I 6 vs. EI 1 - EI 6 and I 7 - I 12 vs. EI 7 - EI 12; Table 3, 4). In the unexposed group of animals Ascaris suum infestation led to a significant increase in metabolic activity of phagocytes and in the proliferative activity of Tlymphocytes in comparison with exposed rats.

In the second collection (Day 8 after infestation) mean values of IMA of phagocytes were significantly different between exposed and exposed and infested rats (E $7-$ E 12 vs. EI 7 - EI 12; Table 3). compounds affect the function of a variety of cell types, including those of the nervous system, microvascular endothelium, kidney (Razani-Boroujerdi et al., 1999; Müller et al., 2007), and the immune system (Luster et al., 1978; Lawrence, 1981; 1985; Koller, 1990; Fischbein et al., 1993; Cohen et al., 1994; McCabe, 1994). In vivo studies have shown that lead is an immunotoxicant depressing humoral immunity (Koller \& Kovacic, 1974; Koller et al., 1977; Luster et al., 1978), increasing host susceptibility to bacterial (Hemphil et al., 1971; Lawrence, 1981; Fernandez-Cabezudo et al., 2007), and viral infections (Gainer, 1974), reduced resistance to endotoxin (Selye et al., 1966). A hallmark of lead-induced immunotoxicity is a pronounced shift in the balance in Th cell function toward Th2type responses at the expense of Th1-type functions. This bias alters the nature and range of immune responses that can be produced thereby influencing host susceptibility to various diseases (Dietert et al., 2004).

The persistent effect of lead acetate-induced immunotoxicity was studied by Chen et al. (1999). Female Fischer 344 rats were administered $250 \mathrm{ppm}$ lead acetate in drinking

Table 4. Stimulation index of rat peripheral blood lymphocytes after chronic exposure to lead acetate trihydrate and infestation by $A$. suum eggs

\begin{tabular}{cclcc}
\hline Group & Animal & I. collection & Animal & II. collection \\
\hline $\begin{array}{c}\mathbf{C} \\
\text { Mean } \pm \mathrm{SD}\end{array}$ & $1-6$ & $2.95 \pm 0.38$ & $7-12$ & $2.95 \pm 0.30$ \\
\hline $\begin{array}{c}\mathbf{I} \\
\text { Mean } \pm \mathrm{SD}\end{array}$ & $1-6$ & $3.01 \pm 0.43$ & $7-12$ & $3.36 \pm 0.42^{\mathrm{e}^{*}}$ \\
\hline $\begin{array}{c}\mathbf{E} \\
\text { Mean } \pm \mathrm{SD}\end{array}$ & $1-6$ & $2.25 \pm 0.11^{\mathrm{a}^{* *} ; \mathrm{c}^{* *}}$ & $7-12$ & $2.28 \pm 0.10^{\mathrm{f}^{* *} ; \mathrm{g}^{* * *}}$ \\
$\begin{array}{c}\mathbf{E I} \\
\text { Mean } \pm \mathrm{SD}\end{array}$ & $1-6$ & $2.24 \pm 0.09^{\mathrm{b}^{* *} ; \mathrm{d}^{* *}}$ & $7-12$ & $2.68 \pm 0.19^{\mathrm{h}^{* *}}$
\end{tabular}

$\mathrm{C}$ - control; I - infested by A. suum eggs; E - exposed to lead acetate trihydrate; EI - exposed to lead acetate trihydrate and infested by $A$. suum eggs; $* \mathrm{p}<0.05 ; * * \mathrm{p}<0.01 ; * * * \mathrm{p}<0.001$

Significant difference between groups: $\mathrm{a}^{* *}-\mathrm{C}$ and E; $\mathrm{b}^{* *}-\mathrm{C}$ and $\mathrm{EI} ; \mathrm{c}^{* *}, \mathrm{~g}^{* * *}-\mathrm{I}$ and $\mathrm{E} ; \mathrm{d}^{* *}, \mathrm{~h}^{* *}-\mathrm{I}$ and $\mathrm{EI} ; \mathrm{e}^{*}-\mathrm{C}$ and I; $\mathrm{f}^{* *}-\mathrm{C}$ and $\mathrm{E}$

\section{Discussion}

Lead is an ubiquitous environmental contaminant and belongs to the group of most toxic heavy elements in the atmosphere. If animals eat contaminated plants or animals, most of the lead that they eat will pass through their bodies (ATSDR, 2005). Many studies have demonstrated that lead water from 2 weeks prior to mating until parturition. The immune function of the female offspring was tested at 13 weeks of age. The results showed that lead suppressed Th1-type responses delayed type hypersensitivity, IFN- $\gamma$ production, enhanced a Th2-type response IL-4 production, and increased TNF- $\alpha$ production from macrophages (Chen et al., 1999). 
A number of studies have documented that lead exerts immunotoxic effects on T-lymphocytes. In studies designed to explore this general response over a broad dose range, female Swiss mice were administered six different diets containing lead acetate 1 day after mating. During lactation, the mothers received the same feed given during pregnancy, and the same diets were administered to the offspring for 9 months after weaning. At higher dietary lead levels (40 and 400 ppm), a significant increase in IL-4 production was associated with a profound decrease in INF- $\gamma$ and IL-2 production. At the lowest lead diet level $(0.02 \mathrm{ppm})$ increases in INF- $\gamma$ and IL-2 production along with a significant decrease in IL-4 production were observed (Iavicoli et al., 2006).

Not only heavy metals, but also helmith infections and parasite components have a potent immunomodulatory effects on the host immune system and can impair immune responses (Oshiro et al., 2006). One of the most common parasites in pigs and wild boars is the nematode Ascaris suum (Antolová et al., 2006). Pigs given a single inoculation of Ascaris suum eggs expel the majority of larvae between days 14 and 21 post inoculation. In non-specific host larvae migrate into liver and lungs and the role of the immune system in their expulsion is still unclear. According to Miquel et al. (2005) both systemic and mucosal $A$. suum-specific effector mechanisms are strongly stimulated in A. suum single infections and indicate that mucosal IgA may be an important mediator in the expulsion of $A$. suum. Itami et al. (2005) have isolated two distinct components from Ascaris suum adult worms with different effects on the immune system: the allergenic protein of $A$. suum (APAS-3), which induces IgE antibody production, and suppressive protein of $A$. suum (PAS-1), which inhibits humoral and cellular immune responses induced by unrelated antigens. A reduced proliferative capacity of murine T-lymphocytes was caused by $A$. suum extracts (Boitelle et al., 2003).

In guinea pigs with experimental ascariosis administration of industrial heavy metal immissions $(\mathrm{Hg}, \mathrm{Cu}, \mathrm{Pb}, \mathrm{Zn})$ for 5 days showed a significant decrease in T- and B-cell population and in macrophage phagocytic ability during the migration phase of $A$. suum when compared with an infected but untreated group of animals. This was also manifested by an eight-fold increase in the density of migrating ascaris larvae in the lungs. Macrophage metabolic activity in animals given immission was significantly suppressed only until Day 7 post-infection. The most striking decrease in the immunological responses was observed in guinea pigs that were given immission but were not infected (Borošková et al., 1993).

The goal of our study was to determine to what extent rat phagocytes and lymphocytes, exposed to the heavy metal, respond to parasitic infection caused by the non-specific parasite. On the basis of our results lead acetate trihydrate induced an immunotoxic effect in chronically intoxicated Wistar rats. Both types of immune cells, peripheral blood phagocytes and lymphocytes, showed a significant decrease in their functional abilities (metabolic activity of pha- gocytes and mitogenic activation of T-lymphocytes) after a four-month exposure to metal. Infestation with Ascaris suum eggs in unexposed group of animals caused a significant increase in metabolic activity of peripheral blood phagocytes and mild increase in proliferative activity of Tlymphocytes during the period of larvae migration into the lungs. In contrast, in metal exposed rats a non-significant increase in biological activity of phagocytes and lymphocytes was determined during this period. Mean values of IMA and SI in this group were significantly lower than in unexposed infested rats. The same results were found by Šoltýs et al. (1997) with copper and mercury intoxicated guinea pigs, where inhibited phagocytic activity of peritoneal macrophages after $A$. suum infection was observed.

It can be concluded that chronic intoxication with lead acetate trihydrate caused an immunotoxic effect in rats manifested by a significant decrease in functional abilities of phagocytes and T-lymphocytes. Decreased immunological parameters also persisted during Ascaris suum infestation in immunosuppressed rats. Because of the immunosupression there were higher numbers of migratory Ascaris suum larvae in the lungs in lead acetate trihydrate exposed rats in comparison with unexposed ones.

\section{Acknowledgements}

This study was supported by VEGA Grants No. 1/4375/07, 1/0545/08 and the National Reference Laboratory for Pesticides, University of Veterinary Medicine in Košice.

\section{References}

Antolová, D., Reiterová, K., Dubinský, P. (2006): The role of wild boars (Sus scrofa) in circulation of trichinellosis, toxocarosis and ascariosis in the Slovak Republic. Helmithologia, 43: 92 - 97

ATSDR, Agency for Toxic Substances and Disease Registry (2005): Toxicological profile for lead (Draft for Public Comment). Atlanta, GA: U.S. Department of Health and Human Services, Public Health Service

Bishayi, B., Sengupta, M. (2006): Synergism in immunotoxicological effects due to repeated combined administration of arsenic and lead in mice. Int. Immunopharmacol., 6: 454 - 464

Boitelle, A., Scales, H. E., Di Lorenzo, C., Devaney, E., Kennedy, M. W., Garside, P., Lawrence, C. E. (2003): Investigating the impact of helminth products on immune responsiveness using a TCR transgenic adoptive transfer system. J. Immunol., 171: $447-454$

BOROŠKOVÁ, Z., BENKOVÁ, M., ŠoltÝs, J., KRUPICER, I., SIMO, K. (1993): Effects of heavy metals imission on the cellular immunity of guinea pigs with experimental ascariosis. Vet. Parasitol., 47: 245 - 254

BOROŠKOvÁ, Z., ŠOLTÝS, J., KRUPICER, I., ŠIŠKA, F. (1995): Effect of glucan immunomodulator on the immune response and mean helmints infection in lambs on pasture contaminated with heavy metal emissions. Helminthologia, 40: $187-192$ 
Bunn, T. L., Parsons, P. J., Kao, E., Dietert, R. R. (2001): Exposure to lead during critical windows of embryonic development: differential immunotoxic outcome based on stage of exposure and gender. Toxicol. Sci., 64: $57-66$

CHEMINFO (2006): Chemical Profiles Created by Canadian Centre for occupational Health and Safety. Lead acetate, http://www.intox.org/databank/documents/chemi $\mathrm{cal} /$ leadacet/cie131.htm

Chen, S., Golemboski, K. A., SAnders, F. S., Dietert, R. R. (1999): Persistent effect of in utero meso-2,3dimercaptosuccinic acid (DMSA) on immune function and lead-induced immunotoxicity. Toxicol., 132: 67 - 79

CoHen, M. D., YANG, Z., ZEliKOFF, J. T. (1994): Immunotoxicity of particulate lead: In vitro exposure alters pulmonary macrophage tumor necrosis factor production and activity. J. Toxicol Environ. Health, 42: 377 - 392

Dietert, R. R., LeE, J.-E., Hussain, I., PiePenbrinK, M. (2004): Developmental immunotoxicology of lead. Toxicol. Appl. Pharmacol., 198: 86 - 94

Fischbein, A., Tsang, P., LuO, J. J., BeKesi, J. G. (1993): The immune system as target for subclinical lead related toxicity. Br. J. Int. Med., 50: $185-186$

Fernandez-CabeZudo, M. J., Ali, S. A., Ullah, A., Hasan, M. Y., Kosanovic, M., Fahim, M. A., AdEM, A., AL-RAMADI, B. K. (2007): Pronounced susceptibility to infection by Salmonella enterica serovar Typhimurium in mice chronically exposed to lead correlates with a shift to Th2-type immune responses. Toxicol. Appl. Pharmacol., 218 (3): $215-226$

GAINER, J. H. (1974): Lead aggravates viral diseases and represses antiviral activity. Environ. Health Perspect., 7: $113-119$

GARCIA, L. S. (2007): Diagnostic medical parasitology. $5^{\text {th }}$ ed., Washington D.C.: ASM Press, $1202 \mathrm{p}$.

Hemphil, F. E., KAEBerle, M. L., BuCK, W. B. (1971): Lead suppression of mouse resistance to Salmonella typhimurium. Science (Wash DC), 172: 1031 - 1032

IARC, International Agency for Research on Cancer Summaries \& Evaluations (2004): Lead and lead compounds: lead and inorganic lead compounds (Group 2b) organolead compounds (Group 3), 10 - 17 February 2004, 87: 230

iavicoli. G., CARelli, E. J., StaneK, I. I. I., CAStellino, N., CALABRESE, E. J. (2006): Below background levels of blood lead impact cytokine levels in male and female mice. Toxicol. Appl. Pharmacol., 210: 94 - 299

InSTITORIS, I., SiroKI, O., Desi, I., UNDEGER, U. (1999): Immunotoxicological examination of repeated dose combined exposure by dimethoate and two heavy metals in rats. Hum. Exp. Toxicol., 18, 2: 88-94

Itami, D. M., Oshiro, T. M., Araujo, C. A., Perini, A., Martins, M. A., Macedo, M. S., Macedo-Soares, M. F. (2005): Modulation of murine experimental asthma by Ascaris suum components. Clinic. Experim. Allergy, 35: $873-879$

Koller, L. D., Kovacic, S. (1974): Decreased antibody formation in mice exposed to lead. Nature (London), 250:
$148-149$

Koller, L. D., Roan, J. G., Brauner, J. A., Exon, J. H. (1977): Immune response in aged mice exposed to lead. $J$. Toxicol. Environ. Health, 3: 535 - 543

Koller, L. D. (1990): The immunotoxic effects of lead in lead-exposed laboratory animals. Ann. NY Acad. Sci., 587: $160-167$

Krupicer, I., PEŤKO, B. (1992): Grazing helmintoses in sheep in the immission region of mercury producing plant. Aktuálna problematika v diagnostike, prevencii a terapii vnútorných chorôb prežúvavcov, 3 - 4 June, 1992, Košice, p. 67 (In Slovak).

KRUPICER, I. (1995): The effect of heavy metal immissions with mercury dominance on the course of grazing helmitoses in sheep. Vet. Med-Czech, 40: $11-15$

KRUPICER, I., JURIŠ, P. (1996): Comparison of grazing helmintoses in sheep between immission region of Central Spiš and ecologically slightly polluted area of Horný Liptov. Zborník Hygienické a ekologické problémy vo vzt’ahu $k$ veterinárnej medicine, Košice, 1996, 205 - 211

KRUPICER, I., VELEBNÝ, S., LEGÁTH, J. (1996): Effect of emissions from mercury treating metallurgical works on the intensity of experimental Fasciola hepatica infection in sheep. Vet. Med.-Czech, 41: $103-106$

LAWRENCE, D. A. (1981): Heavy metal modulation of lymphocyte activities: II. Lead, an in vitro mediator of Bcell activation. Int. J. Immunopharmacol., 3: 153 - 161

LAWRENCE, D. A. (1985): Immunotoxicity of heavy metals. In: DeAn, J. H., Luster, M. I., Munson, A. E., Amos, H. (Eds): Immunotoxicology and Immunopharmacology, Raven Press, New York, pp. 341 353

LoKaJ, V., OBurkova, P. (1975): Stanovení tetrazoliumreduktázové aktivity leukocytú. Imunol. Zprav., 6: 42 - 44 Luster, M. I., FAith, R. E., Kimmel, C. A. (1978): Depression of humoral immunity in rats following chronic developmental lead exposure. J. Environ. Pathol. Toxicol., 1: $397-402$

MCCABE, M. J. (1994): Mechanisms and consequences of immunomodulation by lead. In: DEAN, J. H., LUSTER, M. I., Munson, A. E., KiMBer, I. (Eds): Immunotoxicology and Immunopharmacology, $2^{\text {nd }}$ ed., Raven Press, New York, pp. $143-162$

Miquel, N., Roepstorff, A., Bailey, M., Eriksen, L. (2005): Host immune reactions and worm kinetics during the expulsion of Ascaris suum in pigs. Parasite Immunol., 27: $79-88$

Müller, Y. M., Rivero, L. B., Carvalho, M. C., Kobus, K., FARINA, M., NAZARI, E. M. (2007): Behavioral impairments related to lead-induced developmental neurotoxicity in chicks. Arch. Toxicol., (in press)

Oshiro, T. M., Enobe, C. S., Araújo, C. A., Macedo, M. S., MACEDo-SoAres, M. F. (2006): PAS-1, a protein affinity purified from Ascaris suum worms, maintains the ability to modulate the immune response to a bystander antigen. Immunol. Cell Biol., 84: 138 - 144

Pistl, J., Mikula, I., KruPICER, I., ŠNiRC, J. (1995): The influence of heavy metal emissions and Fasciola hepatica 
infestation on the immunogenicity of a Listeria vaccine. Vet. Hum. Toxicol., 37: 110 - 112

RAZANi-Boroujerdi, S., EdWARds, B., SOPORI, M. L. (1999): Lead stimulates lymphocyte proliferation through enhanced T cell-B cell interaction. J. Pharmacol. Experim. Therapeutics, 288: 714 - 719

Selye, H., TuchWEBER, B., BertoK, L. (1966): Effect of

RECEIVED JANUARY 16, 2008 lead acetate on the sceptibility of rats to bacterial endotoxins. J. Bacteriol., 91: $884-890$

ŠoltÝs, J., BorošKovÁ, Z., DvorožŇÁKovÁ, E. (1997): Effects of concurrently administered copper and mercury on phagocytic cell activity and antibody levels in guinea pigs with experimental ascariasis. J. Helmithol., 71: 339 344

ACCEPTED FEBRUARY 22, 2008 